\title{
SISTEM PENCARIAN KATALOG BUKU MENGGUNAKAN METODE NAIVE BAYES CLASIFIER (NBC) PADA APLIKASI MULIA-BOOKSTORE BERBASIS ANDROID
}

\author{
${ }^{[1]}$ Abdi Pandu Kusuma, ${ }^{[2]}$ Ida Srirahayu \\ ${ }^{[1],[2]}$ Universitas Islam Balitar
}

\begin{abstract}
Abstrak: Pencarian data buku merupakan serangkaian proses pencarian data untuk mendapatkan sebuah data, informasi barang yang dibutuhkan. Pencarian data bisa menggunakan alat bantu yang bisa disebut aplikasi. Pada penelitian ini aplikasi pencarian data buku dikembangkan pada Toko Mulia Blitar. Aplikasi yang diterapkan dalam penelitian adalah aplikasi pencarian data yang dilakukan secara otomatis menggunakan aplikasi yang dikembangkan dengan metode Naive Bayes Clasifier dengan pengaplikasian software client berbasis smartphone mobile. Aplikasi server berbasis website berfungsi menginputkan data buku oleh administrator dan aplikasi client berbasis mobile berfungsi sebagai media yang dapat digunakan oleh konsumen untuk mencari data buku. Pada aplikasi Muliabookstore terdapat data buku dengan berbagai judul yang ditampilkan berdasarkan kategori buku. Pada penelitian ini metode Naive Bayes Clasifier diterapkan sebagai metode pencarian data buku dengan menemukan judul buku yang dicari berdasarkan kata kunci yang diinputkan oleh konsumen, sehingga jika buku yang dicari tersedia akan menampilkan data buku secara akurat berdasarkan kata kunci yang diinputkan.
\end{abstract}

Kata Kunci : Katalog buku, Naive Bayes Classifier, android

\section{a. Latar Belakang}

\section{PENDAHULUAN}

Mutu pendidikan telah menjadi sorotan utama di dalam dunia pendidikan baik dari dalam negeri maupun luar negeri, demi terciptanya sumber daya manusia yang berkualitas yang mampu menjadikan dunia lebih maju dan kehidupan yang lebih baik. Hubungan baik dengan pihak Toko Mulia Blitar selaku penyedia tempat untuk melakukan penelitian tugas akhir untuk mencari masalah yang bisa diangkat dalam penelitian untuk memenuhi tugas akhir mahasiswa Teknik Informatika Universitas Islam Balitar Blitar. Dalam perkembangannya Toko Mulia membutuhkan media online untuk memudahkan konsumen dalam pencarian informasi. dengan ini peneliti memutuskan untuk mengangkat tema penelitian dengan media pencarian katalog buku yang berbasis android.

Secara garis besar aplikasi ini terdiri dari client dan server, sisi client aplikasi ini berjalan pada smartphone android, jika didalam komputer menggunakan emulator. Dari sisi server aplikasi berbasis website menggunakan bahasa pemrograman $P H P$ dan database MySQL yang berjalan pada server hostingan.

Sistem aplikasi pencarian katalog buku berada di sisi client yang berjalan pada sistem operasi android. Dapat berjalan optimal dalam android 4.0 ke atas. Pada penelitian ini penulis memberi nama aplikasi client dengan nama Mulia-bookstore. 
Dengan Mulia-bookstore konsumen pencari buku bisa mencari buku hanya dengan mengetikkan kata kunci. Sebagai contoh jika dalam menu pencarian diketikkan kata "Excel" maka buku dengan berbagai judul yang berkaitan dengan kata "Excel" akan muncul.

\section{b. Rumusan Masalah}

1. Bagaimana membangun aplikasi pencarian katalog buku berbasis android ?

2. Bagaimana pengujian dengan metode Naive Bayes Classifier untuk melakukan pencarian katalog buku?

\section{a. Tinjauan Pustaka}

\section{LANDASAN TEORI}

Penelitian yang dilakukan Oleh Selvia Lorena Br Ginting, Reggy Pasya Trinanda (2014), dengan judul penelitian Teknik Data Mining Menggunakan Metode Bayes Classifier Untuk Optimalisasi Pencarian Pada Perpustakaan (Studi Kasus : Perpustakaan Universitas Pasundan - Bandung), Kesimpulan yang diperoleh dari hasil penelitian ini adalah perangkat lunak yang dibangun hanya dapat mencari judul, kategori dan deskripsi dari buku yang dicari tidak meliputi isi dari seluruh buku. Metode Naive Bayes Classifier dapat diimplementasikan pada pengklasifikasian buku sehingga memudahkan pencarian. Selain itu deskripsi juga ditampilkan sebagai hasil pencarian sehingga user bisa melihat kesesuaian keyword dengan buku yang dicari.

Penelitian yang dilakukan oleh Achmad Fahrurozi (2010) meneliti bahwa metode Navie Bayes Clasivier dapat digunakan pada penelitian Klasifikasi Kayu Dengan Menggunakan Naive Bayes - Classifier Secara umum, dapat mengatakan bahwa data yang diperoleh bergantung pada beberapa hal, sebagai berikut:

1. Kamera merupakan perangkat yang menentukan kualitas citra kayu yang diperoleh dan juga ukuran matriks representasi dari citra kayu tersebut.

2. Konstruksi citra FoI dan LBP.

3. Parameter-parameter pembentuk fungsi graycomatrix dalam perangkat lunak Matlab.

Penelitian yang dilakukan oleh Agus Setiawan, Indah Fitri Astuti, Awang Harsa Kridalaksana (2015), meneliti bahwa metode Naive Bayes Clasifier digunakan dalam penelitian yang berjudul Klasifikasi Dan Pencarian Buku Referensi Akademik Menggunakan Metode Naive Bayes Classifier (NBC) (Studi Kasus: Perpustakaan Daerah Provinsi Kalimantan Timur), Sistem klasifikasi dan pencarian buku referensi akademik menggunakan metode Naive Bayes Classifier $(N B C)$ ini merupakan aplikasi yang membantu pihak perpustakaan dalam menentukan kategori yang tepat pada setiap buku serta memudahkan user dalam mencari buku yang sesuai dengan keinginan mereka.

Penelitian yang dilakukan oleh Artha Galang S, Riawan Indra P, Ramadani, Adi Warman (2012) dalam penelitian yang berjudul Pencarian Dan Penentuan Buku Referensi Tugas Akhir Mata kuliah Dengan Metode Naive Bayes Classifier Dan Association Rule menjelaskan bahwa dengan menggunakan metode ini, sistem penentuan buku ini dapat digunakan untuk mengkategorikan buku-buku yang 
jadikan referensi bersama atau buku-buku yang memiliki bahasan materi untuk beberapa kategori. Dalam penelitian ini, telah dibuat sistem penentuan buku yang tidak menggunakan teori probabilitas sebagai dasar klasifikasinya. Sistem tersebut menggunakan perhitungan jumlah frase untuk tiap kategori sebagai dasar klasifikasinya.

Penelitian Yang Dilakukan Oleh Selvia Lorena Br Ginting,S.Si., Mt, Reggy Pasya Trinanda (2012) Dalam Penelitian dengan judul "Penggunaan Metode Naive Bayes Classifier Pada Aplikasi Perpustakaan”. Dengan menggunakan metode ini maka pencarian akan dilakukan lebih mendalam dengan melibatkan deskripsi dari setiap buku, sehingga ada lebih banyak referensi yang ditampilkan dalam pencarian. referensi tersebut berkaitan dengan kata yang di masukkan oleh pengunjung pada mesin pencarian di aplikasi perpustakaan tersebut. Dengan demikian aplikasi yang menggunakan metode Naive Bayes Clasifier dapat membantu pengunjung dalam melakukan pencarian buku yang diinginkan.

\section{b. Aplikasi Client Server Android}

Penjelasan tentang aplikasi Client Server android adalah aplikasi yang memiliki website sebagai server penginput data yang dilakukan oleh administrator yang sistem clientnya dapat berjalan pada sistem operasi mobile berbasis android. Dengan aplikasi Client Server dapat memungkinkan konsumen dapat mencari buku yang dibutuhkan secara cepat dan mudah secara online melalui smartphone android dengan menggunakan aplikasi yang akan dibangun yaitu Mulia-bookstore pada toko buku Mulia Blitar.

Secara garis besar aplikasi Mulia-bookstore dibangun terdiri dari dua sisi yaitu sisi Client dan sisi Server. Aplikasi client yaitu aplikasi yang dibangun menggunakan emulator pada komputer Android studio dan dapat dioprasikan pada smartphone android atau menggunakan dan sisi server aplikasi berbasis website dibangun menggunakan bahasa pemrograman $P H P$ dan database MySQL yang beroprasi pada server domain dan hosting. Untuk menghubungkan antara website server dan aplikasi client dibutuhkan jaringan internet dalam pengupdatean data.

\section{c. Pengertian Teknik Pencarian Buku}

Pada umumnya teknik pencarian buku dalam implementasinya akan dilakukan lebih mendalam dengan melibatkan deskripsi dari setiap buku, sehingga ada lebih banyak judul buku yang di tampilkan dalam pencarian buku. Tentunya judul buku yang muncul tersebut berkaitan dengan kata kunci yang di masukkan oleh user pada sistem pencarian buku pada aplikasi Client Mulia-bookstore. Dengan demikian aplikasi client dirancang dengan tujuan membantu konsumen lebih mudah dalam melakukan pencarian buku judul bukuyang dibutuhkan yang dapat diakses secara online menggunakan media smartphone android.

\section{d. Metode Naive Bayes Clasifier}

Naive Bayes Classifier merupakan sebuah metode klasifikasi yang berakar pada teorema Bayes. Ciri utama dari Naive Bayes Classifier ini adalah asumsi yang sangat kuat akan independensi dari masing-masing kondisi atau kejadian. Sebelum 
menjelaskan Naive Bayes Classifier ini, akan dijelaskan terlebih dahulu Teorema Bayes yang menjadi dasar dari metode tersebut.

Naive Bayes Classifier (NBC). Naive Bayes Classifier merupakan salah satu metode machine learning yang memanfaatkan perhitungan probabilitas dan statistik yang dikemukakan oleh ilmuwan Inggris Thomas.

Bayes, yaitu memprediksi probabilitas di masa depan berdasarkan pengalaman di masa sebelumnya. Dasar dari Naive Bayes yang dipakai dalam pemrograman adalah rumus Bayes:

$P(A \mid B)=P(B \mid A) * P(A)) / P(B)$

Peluang kejadian A sebagai B ditentukan dari peluang B saat A, peluang A, dan peluang B. Pada pengaplikasiannya nanti rumus ini berubah menjadi :

$P(C i \mid D)=P(D \mid C i) * P(C i)) / P(D)$

Naive Bayes Classifier atau bisa disebut sebagai Multinomial Naive Bayes merupakan model penyederhanaan dari Metode Bayes yang cocok dalam pengklasifikasian teks atau dokumen. Persamaannya adalah:

$V_{M A P}=\arg \max P\left(V_{j} \mid a_{1}, a_{2}, \ldots a_{n}\right) \quad \ldots$

Menurut persamaan 3, maka persamaan 4 dapat ditulis:

$V_{M A P}=\underset{v_{j} \in V}{\arg \max } \frac{P\left(a_{1}, a_{2}, \ldots . a_{n} \mid v_{j}\right) P\left(v_{j}\right)}{P\left(a_{1}, a_{2}, \ldots a_{n}\right)}$

$\mathrm{P}(\mathrm{a} 1, \mathrm{a} 2, \ldots \ldots . . . \mathrm{an})$ konstan, sehingga dapat dihilangkan menjadi :

$V_{M A P}=\underset{v_{j} \in V}{\arg \max } P\left(a_{1}, a_{2}, . a_{n} \mid v_{j}\right) P\left(v_{j}\right)$

Karena $\mathrm{P}(\mathrm{a} 1$, a2,.... an $\mid \mathrm{vj})$ sulit untuk dihitung, maka akan diasumsikan bahwa setiap kata pada dokumen tidak mempunyai keterkaitan.

$V_{M A P}=\underset{v_{j} \in V}{\arg \max } P v_{j} \prod_{i} P\left(v_{i} \mid v_{j}\right)$

Keterangan :

$P\left(v_{j}\right)=\frac{\mid \text { docs }_{j} \mid}{\mid \text { Contoh } \mid}$

$P\left(w_{k} \mid v_{j}\right)=\frac{n_{k}+1}{n+\mid \text { kosakata } \mid}$

Dimana Untuk :

$\mathrm{P}(\mathrm{vj})$ : Probabilitas setiap dokumen terhadap sekumpulan dokumen

$\mathrm{P}(\mathrm{wk} \mid \mathrm{vj})$ : Probabilitas kemunculan kata wk pada suatu dokumen dengan kategori class vj

| docs | : frekuensi dokumen pada setiap kategori

| Contoh | : jumlah dokumen yang ada.

Nk : frekuensi kata ke-k pada setiap kategori

Kosakata: jumlah kata pada dokumen test 
Pada persamaan (8) terdapat suatu penambahan 1 pada pembilang, hal ini dilakukan untuk mengantisipasi jika terdapat suatu kata pada dokumen uji yang tidak ada pada setiap dokumen data training.

\section{e. Cara Kerja Naive Bayes Clasifier}

Cara kerja Naive Bayes Classifier melalui dua tahapan, yaitu :

1. Learning (Pembelajaran)

Naive Bayes Clasifier adalah suatu metode yang termasuk ke dalam supervised learning, maka akan

dibutuhkan pengetahuan awal untuk dapat mengambil keputusan. Langkahlangkah :

a. Step 1 : Bentuk vocabulary pada setiap dokumen training

b. Step 2 : Hitung probabilitas pada setiao kategori $\mathrm{P}(\mathrm{vj})$.

c. Step 3 : Tentukan frekuensi setiap kata wk pada setiap kategori $\mathrm{P}(\mathrm{wk} \mid \mathrm{vj})$

2. Classify (Pengklasifikasian). Langkah-langkahnya adalah :

a. Step 1 : Hitung $\mathrm{P}(\mathrm{vj}) \Pi \mathrm{P}(\mathrm{wk} \mid \mathrm{vj})$ untuk setiap kategori.

b. Step 2 : Tentukan kategori dengan nilai $\mathrm{P}(\mathrm{vj}) \Pi \mathrm{P}(\mathrm{wk} \mid \mathrm{vj})$ maksimal.

\section{f. Web Server}

Dalam Pemrograman Aplikasi Android, Web Server adalah sebuah perangkat lunak server yang berfungsi menerima permintaan HTTP atau HTTPS dari client yang dikenal dengan web browser dan mengirimkan kembali hasilnya dalam bentuk halaman-halaman website yang umumnya berbentuk dokumen HTML. Web server yang sering dipakai pengguna pada penelitian adalah Apache. Apache adalah server $\underline{\text { web }}$ yang dapat dijalankan di banyak sistem operasi ( $\underline{\text { Unix }}, \underline{B S D}, \underline{\text { Linux }}, \underline{\text { Microsoft }}$ Windows dan Novell Netware serta platform lainnya) yang berguna untuk melayani dan memfungsikan situs web. Protokol yang digunakan untuk melayani fasilitas website atau $w w w$ ini menggunakan HTTP. Apache memiliki fitur-fitur canggih seperti pesan kesalahan yang dapat dikonfigurasi, autentikasi berbasis basis data dan lain-lain. Apache juga didukung oleh sejumlah antarmuka pengguna berbasis grafik (GUI) yang memungkinkan penanganan server menjadi mudah.

\section{g. MySQL dan PHPMyadmin}

Dalam buku Pemrograman Aplikasi Android MySQL adalah database yang menghubungkan script PHP menggunakan perintah query dan escaps character yang sama dengan PHP. MySQL mempunyai tampilan client yang mempermudah user dalam mengakses database dengan kata sandi untuk mengizinkan proses yang bisa dilakukan.

PHPMyadmin adalah sebuah software yang berbentuk seperti halaman situs resmi yang terdapat pada web server. Fungsi dari halaman ini adalah sebagai pengendali database $M y S Q L$ sehingga pengguna MySQL tidak perlu menggunakan perintah-perintah SQL. Karena dengan adanya halaman PHPMyadmin semua hal tersebut dapat dilakukan dalam penginputan database hanya dengan mengeklik menu fungsi yang ada pada halaman PHPMyAdmin. 


\section{h. Website Editor}

Dalam buku Toko Buku Online Dengan Android menjelaskan Web Editor adalah program yang dapat mempermudah pekerjaan programmer dalam mendesain aplikasi berbasis web ataupun membuat baris kode program. Untuk Web editor dalam perancangan aplikasi ini menggunakan program keluaran Adobe yaitu Adobe Dreamweaver.

\section{i. Software Perancang aplikasi Client \\ 1. Java JDK}

Dalam buku Toko Buku Online Dengan Android menjelaskan JDK adalah singkatan dari Java Development Kit yaitu software yang digunakan untuk membangun aplikasi-aplikasi java. Tanpa JDK perancang aplikasi android tidak akan bisa membangun atau membuat berbagai macam aplikasi java. Download di http:// java.sun.com /javase/ downloads/ ?intcmp $=2817$ atau http:// java.sun.com/ javasel downloads.

\section{Android Studio}

Android Studio adalah sebuah lingkungan pengembangan terpadu (IDE) untuk mengembangkan pada platform Android. Didasarkan pada perangkat lunak IDEA JetBrains 'IntelliJ, Android Studio dirancang khusus untuk pengembangan Android. Android Studio bisa di download pada http:// developer.android.com/ tools/ studio/ index.html

\section{Bluestacks App Player}

Bluestacks App Player adalah software emulator yang dapat digunakan untuk menjalankan aplikasi Android di komputer atau laptop. Melalui aplikasi Bluestacks ini, hampir semua aplikasi Android bisa dijalankan seperti menggunakan smartphone, seperti facebook, whatsapp, BBM, Line, dan Game-game 3D yang keren. Pengguna juga bisa mengintegrasikan akun google play di Bluestacks sehingga bisa mengakses game-game atau aplikasi favorit yang ada di smartphone. Bluestacks bisa didownload pada http://Bluestacks-app-player.id.uptodown.com/

\section{a. Lokasi Penelitian}

\section{METODE PENELITIAN}

Dalam penyusunan laporan penelitian penulis melakukan penelitian dengan mengambil objek penelitian pada tempat Penjualan Buku dan Busana di Toko Mulia Jl.Semeru No.62 Kauman, Kepanjenkidul Kota Blitar.

\section{b. Pengumpulan Data}

1. Studi Lapangan ( Field Research ) adalah pengumpulan data secara langsung ke lapangan

2. Studi literature (Library Research)

Studi kepustakaan seperti mempelajari buku buku referensi yang berhubungan dengan Android dan Aplikasi toko buku online dengan Aplikasi Client Server untuk membantu dalam pembuatan aplikasi Aplikasi Mulia-bookstore. 
3. Merancang dan Mengimplementasi

Merancang dan mengimplementasi aplikasi yang akan dikembangkan agar aplikasi berjalan sesua dengan yang diharapkan.

\section{c. Perancangan Sistem}

\section{Flowchart}

Diagram Alir atau Flowchart merupakan serangkaian bagan yang menggambarkan alir program. pada flowchart ini digambarkan urutan prosedur dalam program Aplikasi Client android Mulia-bookstore.

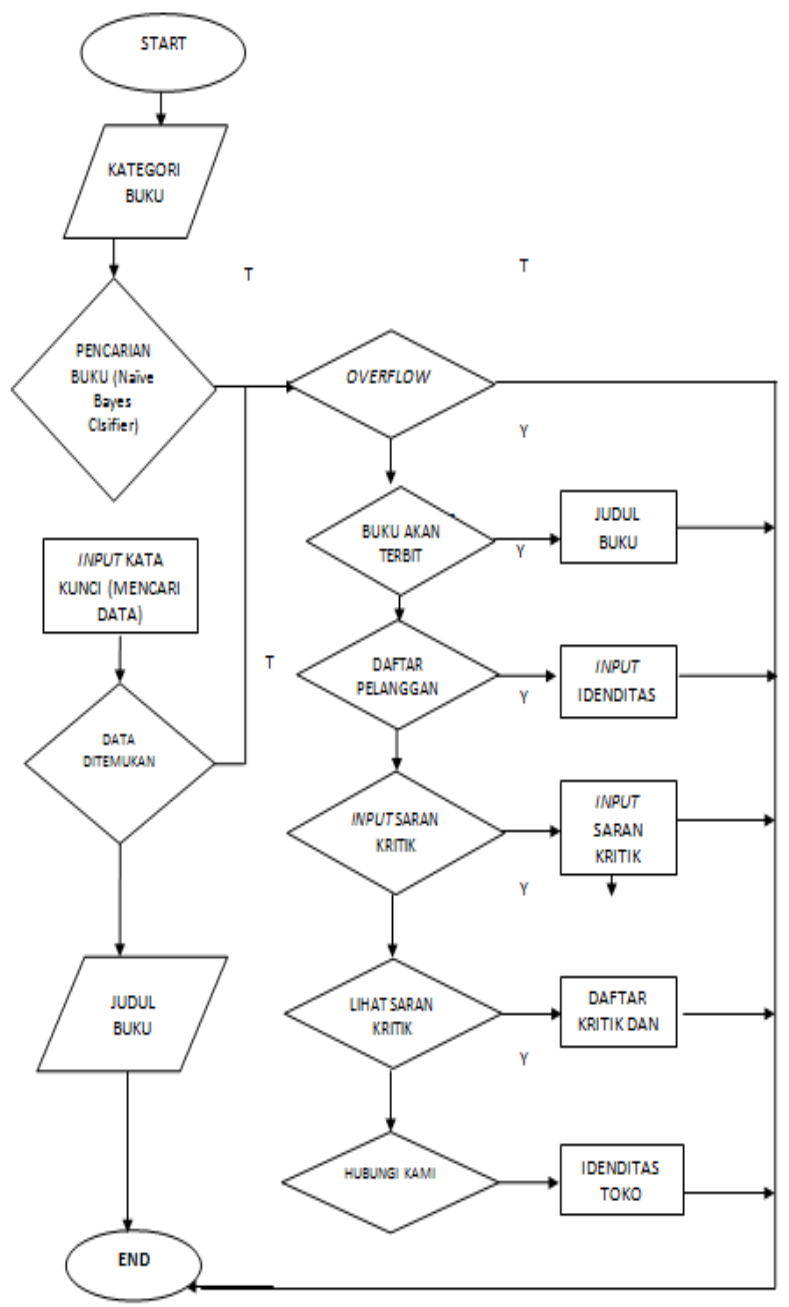

Gambar 1, Flowchart Pencarian Buku Pada Aplikasi Mulia-bookstore

Penjelasan Flowchart pada gambar 1 :

a) Start

Start adalah menu awal untuk memulai Flowchart.

b) Katalog Produk

Katalog Produk terdapat dalam menu utama dalam Aplikasi Client Muliabookstore, Setelah user menggunakan aplikasi ini dalam tampilan menu utama akan terdapat beberapa produk yang ada. 
c) Produk Buku

Produk yang ditampilkan dalam Menu Utama, terdapat beberapa kategori buku didalam menu utama seperti kategori buku pendidikan, peternakan, pertanian, music, buku pelajaran, komik, al-qur'an dan kitab. Didalam beberapa kategori buku terdapat berbagai macam judul buku beserta harganya.

d) Overflow

Overflow adalah menu garis disamping menu utama yang berisi :

1) Buku akan terbit

Adalah menu yang berisi daftar buku yang akan terbit.

2) Daftar pelanggan

Adalah tempat yang digunakan untuk menginputkan daftar pelanggan, yang digunakan dalam proses pembelian buku.

3) Input saran kritik

Adalah tempat untuk menginputkan berbagai saran dan kritik

4) Lihat saran kritik

Adalah menu yang berisikan saran dan kritik yang telah diinputkan oleh user.

5) Hubungi kami

e) End

Adalah menu yang berisikan idenditas Toko Mulia

Adalah menu akhir untuk mengakhiri flowchart

\section{Perancangan Antar Muka Website Server}

Perancangan Interface adalah bagian yang penting dalam aplikasi, karena yang pertama kali dilihat ketika aplikasi dijalankan adalah tampilan antar muka aplikasi

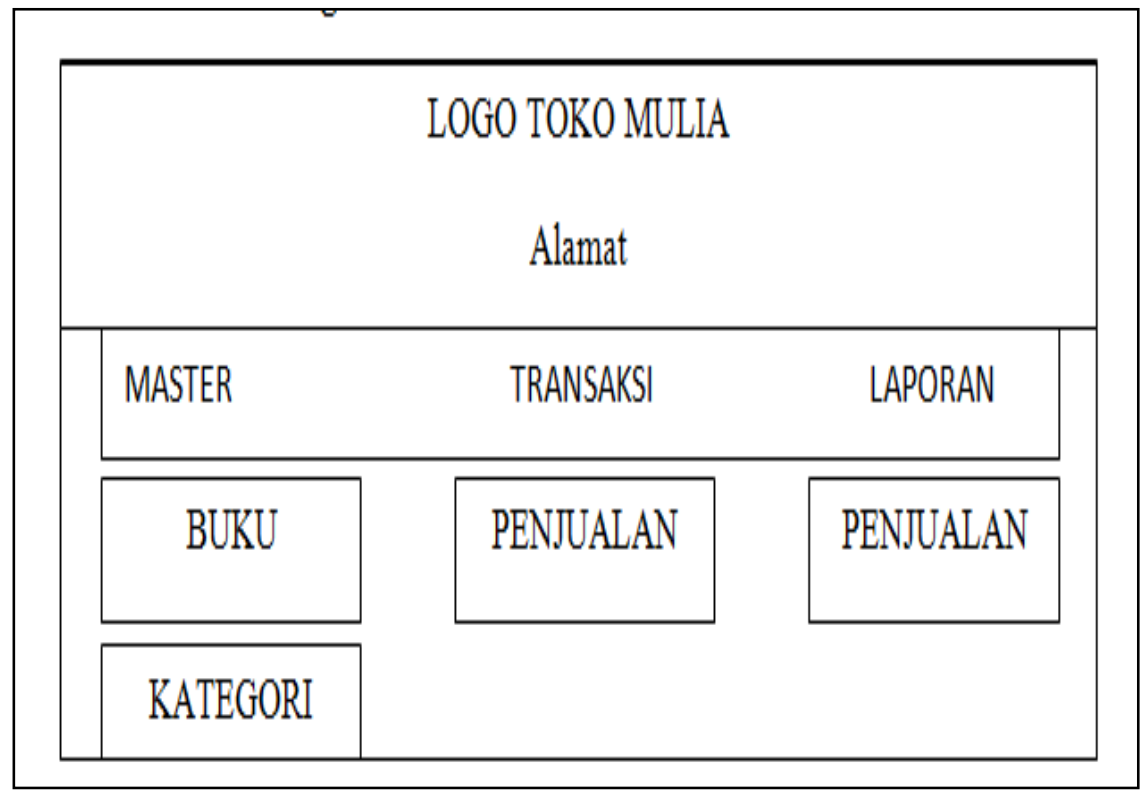

Gambar 2, Desain Menu utama website 


\section{Perancangan Antar Muka Aplikasi Client}

Perancangan Interface adalah bagian yang penting dalam aplikasi, karena yang pertama kali dilihat ketika aplikasi dijalankan adalah tampilan antar muka aplikasi.

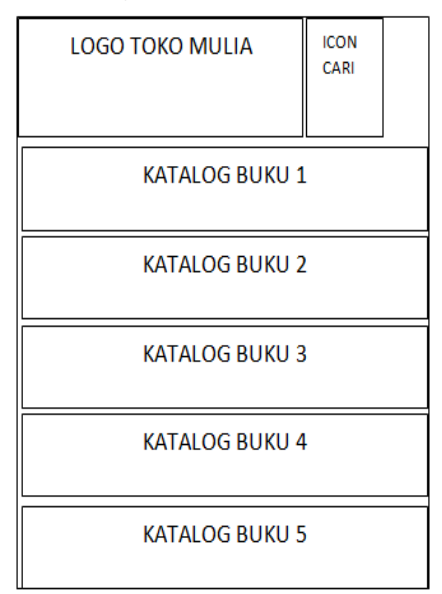

Gambar 3. Desain Menu Utama Aplikasi Client

\section{Perancangan Penalitian}

Dalam penelitian rancang bangun suatu aplikasi, tentu tidak lepas dari peran serta alat dan bahan yang digunakan. Pada penelitian ini dibutuhkan alat berupa perangkat keras dan perangkat lunak.

\section{a) Perancangan Hadware}

Dalam menerapkan rancangan yang telah dijelaskan sebelumnya dibutuhkan beberapa perangkat keras untuk menyajikan aplikasi ini. Adapun alat-alat yang dibutuhkan adalah :

1) Handphone digunakan untuk menjalankan sistem operasi Android yang telah dikembangkan. Adapun handphone yang digunakan adalah smartphone dengan spesifikasi minimal sebagai berikut :

$\begin{array}{ll}\text { Layar } & : \text { LCD (Menyesuaikan) } \\ \text { Processor } & : \text { Intel Atom Z2520 (Menyesuaikan) } \\ \text { Memory } & : \text { Ram 512 Mb ke atas } \\ \text { Storage } & : \text { Internal / Eksternal } \\ \text { Kamera } & : \text { 2 Mp (Menyesuaikan) } \\ \text { Sim Card } & : \text { Dual Sim (Menyesuaikan) } \\ \text { Baterai } & : \text { 1200 Mah (Menyesuaikan) } \\ \text { Sistem Operasi } & : \text { 4.0 (Ice Cream Sandwich) Keatas } \\ \text { Jaringan } & : \text { 2g/3g }\end{array}$

2) Satu Unit PC dengan spesifikasi minimal sebagai berikut:
a. Procesor Core 2 Duo atau diatasnya
b. Mainboard ASUS/Gigabyte/ECS
c. Memory DDR2 $4 \mathrm{~Gb}$ atau diatasnya
d. Harddisk $80 \mathrm{~Gb}$ atau diatasnya
e. Keyboard
f. Mouse 


\section{g. Casing ATX E-Case}

h. LCD Monitor

i. Konektivitas Menggunakan : Wi-Fi, Bluetooth ataupun modem

\section{b) Perancangan Software}

Dalam menerapkan rancangan yang telah dibuat, dibutuhkan beberapa software untuk membuat Aplikasi Client Mulia-bookstore Berbasis Android pada Toko Mulia Blitar, Sebagai berikut :

1. Java Development Kit (JDK) version 1.8.0_05

2. Android Studio

3. Bluestacks App Player

4. Xampp 1.8.1

5. Web Editor Menggunakan Adobe Dreamweaver CS6

\section{HASIL DAN PEMBAHASAN}

\section{a. Pencarian Buku Menggunakan Metode Naive Bayes Classifier (NBC)}

Metode Naive Bayes Clasifier (NBC) adalah salah satu metode yang digunakan dalam aplikasi pencarian data buku berdasarkan klasifikasi, dalam aplikasi Muliabookstore pencarian buku yang dilakukan secara otomatis terbukti lebih mudah dan cepat. Dengan cara menggunakan icon search yang terdapat dalam aplikasi Muliabookstore. Icon search terdapat pada menu home di header terletak dekat dengan menu overflow . Jika mengeklik icon search akan muncul tampilan seperti gambar 4 Tampilan menu pencarian yang bisa digunakan dalam melakukan pencarian buku yang hasilnya akan muncul berdasarkan klasifikasi kata kunci yeng telah diinputkan.

Hasil Pengujian pencarian judul buku berdasakan keyword yang diinputkan membuktikan bahwa metode Naive Bayes Clasifier (NBC) menghasilkan data yang akurat. Yang dapat diuji dengan rumus :

$v_{j}=\frac{\left|\operatorname{docs}_{j}\right|}{\mid \text { contoh } \mid}$

Keterangan :

$\left|\operatorname{docs}_{\mathrm{j}}\right|$ : Frekuensi dokumen pada setiap kategori (Kemunculan kata berdasarkan kata kunci)

|Contoh | : Jumlah dokumen yang ada (Dokumen kata berdasarkan kata kunci)

Pengujian dilakukan pada pencarian berdasarkan kata kunci, dengan menggunakan metode Naive Bayes Clasifier. Sehingga dapat ditentukan judul buku yang merupakan klasifikasi dari keyword yang dimasukkan oleh user misalnya "pendidikan".

TABEL 1

PENGUJIAN METODE NAIVE BAYES CLASIFIER (I)

\begin{tabular}{lc|ccc}
\hline No & docs $_{\mathbf{j}}$ & Contoh & $\mathbf{P}(\boldsymbol{v j})$ & Hasil \\
\hline 1 & 1 & 9 & $1 / 9$ & 0,111111 \\
2 & 1 & 9 & $1 / 9$ & 0,111111 \\
3 & 1 & 9 & $1 / 9$ & 0,111111 \\
\hline
\end{tabular}


TABEL 2

PENGUJIAN METODE NAIVE BAYES CLASIFIER (II)

\begin{tabular}{l|c|c|cc}
\hline No & docs $_{\mathbf{j}}$ & Contoh & $\mathbf{P}(\boldsymbol{v j})$ & Hasil \\
\hline 4 & 1 & 9 & $1 / 9$ & 0,111111 \\
5 & 1 & 9 & $1 / 9$ & 0,111111 \\
6 & 1 & 9 & $1 / 9$ & 0,111111 \\
7 & 8 & 9 & $8 / 9$ & 0,88889 \\
8 & 1 & 9 & $1 / 9$ & 0,111111 \\
9 & 1 & 9 & $1 / 9$ & 0,111111 \\
\hline
\end{tabular}

Dengan melihat nilai $\mathrm{P}(\mathrm{vj})$ akan diambil nilai maksimal atau nilai terbesar untuk nantinya dimasukan ke dalam tabel Probabilitas Naive Bayes Clasifier untuk ditampilkan sebagai hasil akurasi pencarian pada aplikasi.

TABEL 3

PROBABILITAS NAIVE BAYES CLASIFIER

\begin{tabular}{llc}
\hline No & Kode Kategori Buku & Naive Bayes \\
\hline 1 & K-1 & 0,1111111 \\
2 & K-2 & 0,1111111 \\
3 & K-3 & 0,111111 \\
4 & K-4 & 0,111111 \\
5 & K-5 & 0,111111 \\
6 & K-6 & 0,111111 \\
7 & K-7 & 0,888889 \\
8 & K-8 & 0,111111 \\
9 & K-9 & 0,111111 \\
\hline
\end{tabular}

Probabilitas adalah suatu ukuran tentang kemungkinan suatu peristiwa (event) akan terjadi. Probabilitas dinyatakan antara 0 sampai 1 dan dinyatakan dalam desimal 1=100\%. Probabilitas 0 menunjukkan peristiwa yang tidak mungkin terjadi. Probabilitas satu menunjukkan peristiwa yang pasti terjadi. Maka probabilitas dapat didefinisikan sebagai peluang suatu kejadian.

Persentase $P(v j)=\frac{\text { Nilai } P(v j)}{P(v j)_{\max }} \times 100 \%$

TABEL 4

PERSENTASE PROBABILITAS

\begin{tabular}{llcc}
\hline No & Kode Kategori Buku & Naive Bayes & Persentase P(vj) \\
\hline 1 & K-1 & 0,1111111 & $11,11 \%$ \\
2 & K-2 & 0,1111111 & $11,11 \%$ \\
3 & K-3 & 0,1111111 & $11,11 \%$ \\
4 & K-4 & 0,1111111 & $11,11 \%$ \\
5 & K-5 & 0,1111111 & $11,11 \%$ \\
6 & K-6 & 0,1111111 & $11,11 \%$ \\
7 & K-7 & 0,888889 & $88,89 \%$ \\
8 & K-8 & 0,1111111 & $11,11 \%$ \\
9 & K-9 & 0,1111111 & $11,11 \%$ \\
\hline
\end{tabular}


Berdasarkan tabel 3, Tabel persentase probabilitas maka dapat disimpulkan bahwa pencarian buku "pendidikan" dengan metode Naive Bayes Classifier pada aplikasi mobile Mulia-bookstore terdapat akurasi tertinggi 88,89\%. Dengan penjelasan pencarian pada aplikasi Mulia-bookstore ditampilkan pada gambar 4 dan gambar 5 .

Berikut hasil pengujian dengan memasukkan kata "pendidikan" dalam kolom pencarian.

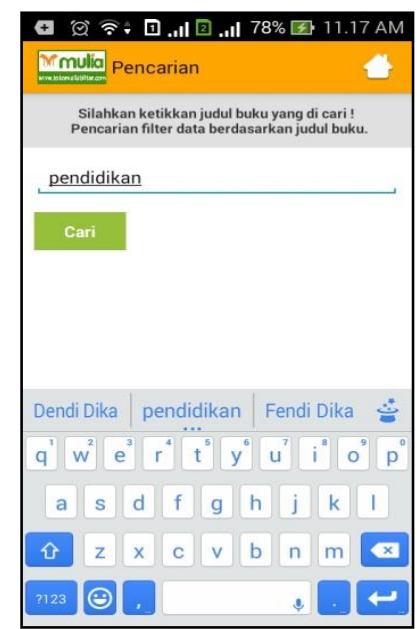

Gambar 4, Tampilan menu pencarian

Pada menu pencarian tersedia kolom untuk memasukkan kata kunci judul buku yang akan dicari. Cara pengoprasian menu pencarian bisa dimulai dengan memasukkan kata kunci dan mengeklik button cari, tunggu sampai sistem memunculkan data buku dari kata kunci yang diinputkan. sebagai contoh pada gambar 4 user menggunakan kata kunci "pendidikan". Jika ada buku dengan judul yang mangandung unsure kata excel maka semua judul buku yang memiliki kata pendidikan akan muncul dalam pencarian.

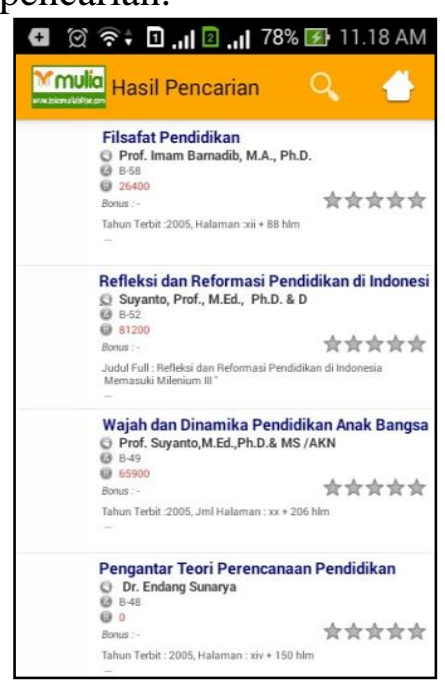

Gambar 5, Hasil pengujian algoritma Naive Bayes Clasifier 
Dari pengujian pada tabel 1, tabel 2 dan tabel 3 dan hasil pengujian pada gambar 5 dapat diketahui bahwa aplikasi Mulia-bookstore dengan menggunakan metode Naive Bayes Clasifier memenuhi beberapa spesifikasi dan kelebihan, yakni :

1. Aplikasi Mulia-bookstore dengan menggunakan metode Naive Bayes Clasifier dapat digunakan untuk pencarian data atau judul buku berdasarkan kata kunci dengan hasil ditunjukkan pada gambar 5.

2. Metode Naive Bayes Clasifier dapat digunakan untuk mengklasifikasikan data sehingga pencarian buku dapat dilakukan dengan lebih optimal dan akurat, karena Aplikasi Mulia-bookstore dengan menggunakan metode Naive Bayes Clasifier melakukan pengklasifikasian dari judul, kategori, pengarang serta deksripsi dari buku yang sudah dicari dengan tampilan pada gambar 5 .

3. Hasil pencarian yang dilakukan berdasarkan kata kunci cukup efisien berdasarkan loading pada database dan penampilan hasil pencarian dengan cepat dan akurat dengan pengujian probabilitas pada tabel 1, tabel 2 dan tabel 3.

\section{SIMPULAN}

Berdasarkan penelitian yang telah dilakukan dengan pada toko Mulia Blitar dengan laporan penelitian yang berjudul "Sistem Pencarian Katalog Buku Menggunakan Metode Naive Bayes Classifier (NBC) Pada Aplikasi Mulia-bookstore Berbasis Android", dapat ditarik kesimpulan, diantaranya :

1. Secara garis besar aplikasi Mulia-bookstore terdiri dari client dan server, sisi client aplikasi ini berjalan pada smartphone android, dari sisi server aplikasi berbasis website. Dari sisi server administrator bertugas mengelola website dengan menginputkan data buku yang selanjutnya data buku tersebut bisa diakses oleh user atau konsumen dengan menginstal aplikasi Mulia-bookstore pada smartphone dan konsumen bisa melihat dan mencari data buku yang diinput oleh admin dengan bantuan aplikasi Mulia-bookstore.

2. Hasil dari penelitian membuktikan bahwa pengujian yeng dilakukan dengan metode Naive Bayes Clasifier (NBC) pada aplikasi Mulia-bookstore menghasilkan persentase keakuratan pencarian data dengan persentase probabilitas Naive Bayes Clasifier sebesar $88,89 \%$.

\section{DAFTAR PUSTAKA}

A.Fahrurozi. 2010. Penelitian Klasifikasi Kayu Dengan Menggunakan Naive Bayes - Classifier. 3(2):4-7.

A.Kadir. 2013. From Zero to a Pro-Pemrograman Aplikasi Android. Yogyakarta: Andi.

A.Kadir. 2008. Dasar Pemrograman Web Dinamis Menggunakan PHP. Yogyakarta: Andi.

A. Kadir. 2004. Aplikasi Program PHP dan MySQL Untuk Membuat Website Interaktif. Yogyakarta: CV Andi Offset. 
A.S.Galang, R.P Indra, Ramadani dan A.Warman. 2012. Pencarian Dan Penentuan Buku Referensi Tugas Akhir Mata kuliah Dengan Metode Naive Bayes Classifier Dan Association Rule. . 1(11):1-6.

A. Setiawan, I. F. Astuti dan A. H. Kridalaksana. 2015. Klasifikasi Dan Pencarian Buku Referensi Akademik Menggunakan Metode Naive Bayes Classifier (NBC) (Studi Kasus: Perpustakaan Daerah Provinsi Kalimantan Timur). 10(1):1-10.

B.Nugroho. 2014. Panduan Membuat Aplikasi Program Toko Berbasis Web Dengan PHP-MySQL Dan Dreamweaver. Yogyakarta: Gava Media.

K. Wahana. 2009. PHP Programming Semarang. Yogyakarta: Andi Publisher.

M. Sadeli. 2014. Toko Buku Online Dengan Android. Palembang: Maxikom.

S.F.Rodiyansyah dan E.Winarko. 2012. Klasifikasi Posting Twitter Kemacetan Lalu Lintas Kota Bandung Menggunakan Naive Bayesian Classification.6(1):94-100.

S. L. Br Ginting dan R. P. Trinanda. 2014. Teknik Data Mining Menggunakan Metode Bayes Classifier Untuk Optimalisasi , Pencarian Pada Perpustakaan (Studi Kasus : Perpustakaan Universitas Pasundan - Bandung). 1(6):1-14. 